\title{
Corporate Governance, Ownership Structure and Stock Market Liquidity in Saudi Arabia: A Conceptual Research Framework
}

\author{
Abdulaziz Mohammed Alsahlawi ${ }^{1}$ \& Mohammed Abdullah Ammer ${ }^{1}$ \\ ${ }^{1}$ Department of Finance, College of Business Administration, King Faisal University, Al-Hasa, Saudi Arabia \\ Correspondence: Mohammed Abdullah Ammer, Department of Finance, College of Business Administration, King \\ Faisal University, Al-Hasa, Saudi Arabia
}

Received: August 8, 2017

Accepted: August 28, 2017

Online Published: September 1, 2017

doi:10.5430/afr.v6n4p17

URL: https://doi.org/10.5430/afr.v6n4p17

\begin{abstract}
This paper aimed to provide a review of the literature concerning the effects of corporate governance and ownership structure on the devices of market microstructure. It provided a clear overview of empirical archival studies in literature regarding the way corporate governance and ownership structure mechanisms influence market liquidity, with focusing on the Saudi institutional setting. It aimed to pinpoint the differences and similarities in empirical outcomes of studies and determine the areas that call for further exploration. On the basis of the thorough review of literature and the theoretical basis, our study proposed a conceptual research framework. The framework is based on the premise that effective corporate governance can lead to enhanced disclosure quality, which in turn, lead to mitigating the information asymmetry and ultimately, enhanced market liquidity. Although theoretical studies argued the presence of the relationship between corporate governance, ownership and liquidity, we find that outcomes from empirical studies are still mixed. Majority of extant studies, with majority in the context of the U.S. firms, provide ambiguous results, making it challenging to reconcile the differences among them. Our paper provides important guidance for both new and experienced researchers, and it has implications for stock exchange authorities in terms of adopting effective regulatory policies and efficient trading systems to tackle information asymmetry.
\end{abstract}

Keywords: Corporate Governance, Ownership Structure, Stock Market Liquidity, Saudi Arabia

\section{Introduction}

Following the recent global financial crisis, stock liquidity has transformed into a global concern and continues to be a major research area in the field of market microstructure (Ali et al., 2016). Capital markets work at facilitating access to investment funds and as such, they play a key role in the sustainable development of the country (Rajan $\&$ Zingales, 1998). Nevertheless, emerging countries, particularly those that need such access, have market characterized by low liquidity (Silva \& Chávez, 2008).

In fact, due to low and lack of liquidity, emerging markets are highly volatile and this prevents the development of their financial markets. In the perspective of investors, liquidity costs have a major role in investment strategies (Silva \& Chávez, 2008). Liquidity costs of firms increase the capital cost and reduces market value and in countries, low liquidity prevents investment, and eventually the development of the economy. The pioneering study to evidence that market liquidity can drive market declines came from Amihud et al. (1990). According to them, the 1987 stock market crash can be attributed to the across the board revision of investors' expectations concerning the stock market liquidity. Because market liquidity is priced in the stock market (Amihud \& Mendelson, 1986), a dip in the expectations of investors concerning such liquidity can lead to stock prices decrease (Rösch \& Kaserer, 2014). Moreover, liquidity has a major role to play in both hedging and risk management as evidenced by Das and Hanouna (2009) and in initiating and driving financial crisis (Wang, 2013). Therefore, liquidity can be described as a key measure of market quality and a crucial pre-requisite for the growth and development of the financial markets.

In the present paper, the financial literature concerning market liquidity is reviewed, with the objective of providing a clear picture of the topic and access to it to novice researchers searching for pointers to examine in this field. In particular, this study has the following primary aims; 1) To review the institution setting of the Saudi Stock Market, 2) To provide a review of prior empirical evidence on the impact of corporate governance mechanisms on market liquidity, 3) To provide a review of prior empirical evidence concerning the impact of ownership structure on market liquidity, 4) To bring forward a conceptual research framework explaining the relationship between corporate 
governance, ownership and market liquidity, and lastly, 5) To provide recommendations for future studies concerning avenues for research.

In Saudi Arabia, the Saudi Vision 2030 drawn up in 2016 envisions the development of an advanced financial and capital market that is accessible from any part of the globe, enabling higher funding opportunities and triggering economic growth. It also envisions the continuous facilitation of the Saudi government of the access to investing and trading in stock markets and listing private Saudi firms and state-owned ones like Aramco. This calls for the need to deepen liquidity in Saudi capital markets to support the role of the debt market and open avenues for derivatives market. In this regard, a greater level of ownership could influence liquidity as retail investors are expected to be net sellers with more foreign capital injected to the market. In the current times, the retail investors constitute $85 \%$ of the trading, despite the fact that ownership accounts for only 1/3rd of the market (Al Rajhi Capital, 2014).

In Saudi Arabia, corporate governance issues vary from those found in the west because successful Saudi companies are mostly family-run with ownership concentration. The members of the family hold a great portion of the equity stake and major positions as directors. Aside from them, the government is increasingly investing in the Saudi stocks in the past few years and such activity is considered to influence the stock market liquidity.

Several studies can be noted on the impact of corporate governance in developed markets involving different aspects (e.g., liquidity, transaction cost, trading mechanism, and trade size), but in the context of Saudi Stock Market, such studies are quite few and far between. Among them, Al-Suhaibani and Kryzanowski (2000) revealed that liquidity, commonly gauged through width and depth, is relatively low in the Saudi stock market case but exceptionally high when gauged through immediacy.

Financial literature has been recently focused on the relationship between market microstructure and corporate finance, with special emphasis on the relationship between corporate governance and market liquidity. For instance, Kanagaretnam et al. (2007), Rubin (2007), and Chung et al. (2010) laid emphasis on the role of corporate governance in enhancing stock liquidity. According to them, effective control mechanisms like driving firms to disclose information and hiring independent directors could mitigate the risk of expropriation and enhance profitability. The use of such mechanisms also mitigates issues of information asymmetry between majority and minority shareholders, and ultimately, increase stock liquidity. Theoretically, corporate governance impact stock market liquidity as effective governance pay strict oversight over managers and hence, stopping them from concealing crucial information. Therefore, effective governance is considered to enhance transparency, and lessen information asymmetry (Chung et al., 2010; Prommin et al., 2014). With less information asymmetry, providers of liquidity are faced with lower negative adverse selection issues (Glosten \& Milgrom, 1985). Consequently, firms having higher governance are expected to display higher equity liquidity.

Furthermore, corporate governance covers the board effectiveness processes and improved transparency when it comes to disclosures. The above requirements lead to enhanced quality and quantity of information accessible to investors. Hence, effective corporate governance assists in developing a dynamic and efficient capital market and investor's confidence in the markets, with companies having higher corporate governance standards.

Empirical studies dedicated to developed markets indicated that internal and external corporate governance mechanisms should be employed to enhance stock market liquidity (e.g., Bacidore \& Sofianos, 2002). More specifically, Jain et al. (2008) reported that the Sarbanes Oxley Act 2002 had significant and positive liquidity effects in the long term. They added that these improvements positively related with financial reports quality. In relation to this, majority of prior studies of this caliber in developed markets indicating high liquidity also indicated protection for investors and dispersed ownership. On the other hand, only a few studies delved into this issue in the context of emerging markets (e.g., Matoussi et al., 2004; Belkhir \& Bouri, 2008; Haddad et al., 2009; Louki \& Yousfi, 2010). They revealed that these markets are characterized by different features such as poor regulation, low market liquidity and high ownership concentration. Without investors' state guarantees, the major agency issues crop up between minority and majority shareholders (Ben Ali, 2009).

According to Sakawa et al. (2014), concentrated ownership structure has a tendency to be rife with problems of lower disclosure quality and lack of transparency. In widely held companies, the shareholders with large company stakes might incur higher agency costs in their monitoring owing to the superior private managers-investors information. In particular, block shareholders lessen market liquidity because of their access to private information among investors and the market risk increase (Heflin \& Shaw, 2000; Rubin, 2007). For instance, Attig et al. (2006) indicated that large control rights could trigger poor disclosure among Canadian firms, and this leads to low liquidity owing to the selfish behaviors of ultimate shareholders who hold large shareholdings. Such poor disclosure nurtures asymmetric information issues in financial markets and ultimately, this leads to reduced market liquidity (Glosten \& 
Milgrom, 1985).

Therefore, the combination of corporate finance and microstructure enables the present study to contribute to literature in several ways. First, literature concerning market microstructure reports several factors influencing liquidity (e.g., company size, trading volume, volatility of return, among others). Moreover, there are only few empirical studies on the effect of corporate governance and ownership on liquidity. This study contributes to this field by extending literature on corporate governance quality and stock market liquidity. Second, majority of past studies focused on the U.S. in their examination of the influence of corporate governance and ownership on liquidity. Hence, this study delves into the issue in the context of Saudi Arabia, an emerging market. Saudi Arabia has notable institutional differences that make it a unique venue to explore the topic in. Third, this study has significant implications to regulators and their understanding of the way corporate policies influence microstructure properties as this could lead to the creation of suitable trading regulators. The study may also provide some information to investors and traders to develop effective trading strategies.

The remaining part of the paper is organized in the following way; Section two contains the institutional setting of Saudi Arabia, and section 3 provides the theoretical background and literature review of the phenomenon under study. Lastly, section 4 presents the conclusion and suggestions for future research.

\section{Institutional Setting of Saudi Arabia}

\subsection{The Saudi Equity Market}

Saudi Arabia is known for being the largest country in size in the Arabian Peninsula and the largest market economy among the Arab nations (Alsaeed, 2006), with 25\% of the total Arab gross domestic product (GDP) (Ministry of Foreign Affairs, Saudi Arabia, 2005). It stands out from its neighboring Arab countries due to its large oil resources resources that have resulted in considerable increase in the country's gross national product (GNP). With the growth resulting from the GNP, the government has decided to boost its investment activity. Added to this, Saudi Arabia is known to be the highest income country in the Arab region (FTSE Global Markets, 2006), with frequent high budget surpluses that drive the Saudi government to invest its financial reserves locally in order to encourage economic development and investments from the local and foreign fronts. The government should thus foster effective corporate governance practices and quality reporting.

Evidently, the Saudi stock market is among the developing markets displaying rapid development in the Middle East and Asia. In fact, the Saudi market with its rapid growth in companies and volume holds significant potential to become a leading market in the region. However, in order to achieve such position, it needs to tackle some challenges that are present within the market system. Looking back at the history of Saudi stock market, 14 firms were in operation in 1975, after which in the 1980s, market developments showed a marked increase after the increase in oil prices (in 1973). The Saudi Shares Registration Company (SSRC) was established for the management of shareholders records and share certificates. Developments continued through the 1990s to the present time. According to the World Federation of Exchange 2002 market capitalization statistics, the Saudi stock market took the 9th rank in the global emerging market. By 2003, the Saudi market indicated more positive developments (Alajlan, 2015).

The Saudi stock market appears to be transitioning with the government floating 30\% of the Saudi Telecom Company (STC), increasing the market capitalization to U.S.\$701,410 billion in April 2004. Within the Arab world, the Saudi Arabian stock market is deemed to be the largest with market capitalization equating to $79 \%$ of all Arab stock markets. Nevertheless, challenges are rife in that the Saudi market, like the markets in developing countries, lacks robust frameworks for regulation, transparency, and disclosure of pertinent financial information that are all significant for the stock exchange development (Alajlan, 2015).

By the year 2014, the aggregate market capitalization of the countries in the MENA region reached U.S.\$1.2 trillion, with Saudi Arabia, constituting $45 \%$ of the total share and $65 \%$ of the U.S. $\$ 4$ billion liquidity levels. With regards to the volume of trading per day, it reached U.S.1.4 billion per day on average, indicating the highest value among the neighboring countries. Consequently, the Saudi equity market is considered to be the largest in the MENA region, having market capitalization of U.S. $\$ 464.5$ billion on average in the year 2015 . The economic liquidity level is evaluated based on the money supply in terms of economic, foreign direct investments (FDI) and consumer level of spending (Jeddah Economic Gateway, 2015).

In relation to the above background, the opening of domestic Saudi financial markets to global investors, as part of the financial liberalization was geared towards improving local market liquidity. This was elaborated by Stulz (1999a) when he stated that the participation of large international financial institutions would lead to improved local market 
liquidity via superior information disclosure and dynamic trading. Also, Bekaert et al. (2007) illustrated a positive effect from the openness level to foreign investors to liquidity, in the case of emerging equity markets.

\subsection{Corporate Governance Structure in Saudi Arabia}

In Saudi Arabia, the corporate governance reforms began in 2003 with the setting up of Capital Market Authority (CMA) (Al-Nodel \& Hussainey, 2010). The reforms form a considerable part of the country's economic reforms and their setting up was urged by the emphasis laid on corporate governance following the collapse of Enron and WorldCom in the developed countries and the 1997/1998 Asian economic crisis (Haniffa \& Hudaib, 2006; Hussainey \& Al-Najjar, 2012). In this background, the capital markets smooth functioning requires the participants' confidence in the corporate governance system. Failed businesses have led to the raised concerns about the lack of robust oversight mechanisms and the lack of corporate governance systems among firms. This is particularly true as such failure lead to the deterioration of investors' confidence.

Notably, early and rapid progress that took place in 2004, within the market capitalization served to direct the CMA direction from introducing corporate governance codes since its inception in 2003. However, owing to the sharp share prices increase, the Saudi stock market indicated a sharp decline in 2006, and this necessitated a governance code to improve the corporate governance practices among Saudi listed companies. To compound the matter further, the market crash led to the passing of governance legislation in light of protecting investors and in relation to this, the stock market crash forced the launching of Saudi Corporate Governance Code (SCGC) in November 2006, with the aim of gaining the investors' confidence back in the market and in protecting their interests (Al-Abbas, 2009). The Code was considered as a guideline until early 2010 when it passed mandatory regulations - where Saudi listed firms were then mandated to disclosure of provisions in their annual report, or justify the lack thereof.

As for the reporting reforms, among the pioneering accounting standards in Saudi Arabia was the standard of disclosure and transparency issued by the Ministry of Commerce and Investment back in 1985. The same was made up-to-date by the Saudi Organization for Certified Public Accountants (SOCPA) in 2002. Among the disclosure reform is the commitment of Saudi Arabia to completely implement the International Financial Reporting Standards (IFRS) by 2017, with the aims of enhancing high-quality reporting and transparency. Nevertheless, when it comes to non-financial disclosure requirements, the country's rules are still poor, particularly in light of some information aspects like the corporate governance-related information as well as beneficial ownership (World Bank, 2009).

\subsection{Ownership Structure in Saudi Arabia}

Despite the fact that the market in Saudi Arabia is rife with issues like concentrated liquidity in the hands of a few, influential shareholders, institutions or government, it is evident that it holds significant potential to achieve world class status. The top unique feature of the Saudi economy is the expansive presence of family ownership when it comes to business structures. This is evidenced by the fact that from 10 of the largest Saudi companies in terms of turnover/sales, 5 are family-owned, with the inclusion of Kingdom Holding Company, which is owned by Prince Al-Waleed bin Talal. In addition, the fourth and the ninth biggest company, which are Dallah Al-Baraka Group and Olayan Financing Company are owned by Saleh Kamel and Olayan families respectively. Also, the government owns a significant portion of the companies, but family-owned businesses accounts for $70 \%$ of the volume of extant firms in Saudi Arabia (Alajlan, 2015). This necessitates developing and regulating the current system to attract the injection of foreign investments in the country.

Most Saudi listed companies frequently have four shareholder groups, which are state, family, institutions and blockholders. In this regard, owing to the importance of ownership structure and its close relationship with agency issues, the Saudi regulations stipulate the disclosure of ownership that exceeds $5 \%$ as well as the board ownership. Such disclosure is stipulated for the managers, directors, outsiders and other related associates. To promote transparency in the companies' contracts and to steer clear of insiders' exploitation, the board has to provide a detailed information of the interests linked to any board of director, the CEO, the Chief Financial Officer (CFO) and the commercial transactions and the firm contracts (Albassam, 2014).

\section{Theoretical Background and Literature Review}

\subsection{Theoretical Background}

In this section, the theoretical framework is presented wherein the different sets of theories are explored to shed insight into the corporate governance and ownership-liquidity relationship.

The agency theory provided that the efficiency of an ownership structure hinges on its coping ability with the conflicts raised by the distinction between ownership and control (Næs, 2004). These conflicts concern a core 
variable namely, informational asymmetry. To this end, the governance practices have to provide and maintain shareholders' rights and ensure that information asymmetry is mitigated along with the agency conflict between minority and controlling shareholders as this can significantly impact managers (La Porta et al., 2000).

With regards to and because of the agency conflict, managers may be urged to hide some pertinent information or manipulate it. Such opportunistic and inefficient management activities are expected to lead to selective information disclosure. This is availed on to hide inefficiencies or expropriation of wealth and this could mean more increased information asymmetry (Prommin et al., 2014). Nevertheless, with firms characterized by robust governance, managers are monitored more strictly through mechanisms and are therefore, not as able to hide information. Hence, stronger governance is considered to lessen information asymmetry for the firm, and as such, it increases firm transparency (Leuz et al., 2003). In theory, investors holding greater firm information are expected to be more inclined to invest, indicating greater confidence in and demand for firms securities that are listed in their sectors and this ultimately leads to increased shares liquidity (Silva et al., 2014).

Moving on to the market microstructure theory, it has challenged the basic notion of the efficiency theory that posits hazard as the major determinant of asset price (Tissaoui \& Ftiti, 2016). According to Andersen (1996), market microstructure theory explains that asset returns are produced from novel information that arises from the market. Hence, market microstructure theory posits that informational advantages may be obtained from the market liquidity via higher trading costs, with a large proportion of shareholders exploiting information could leave other investor interests unprotected. Such access to information negatively influences the adverse selection component of spread, a wider bid-ask spread as well as a lower quoted depth (Yosra \& Sioud, 2011).

This led the researchers to concentrate on two hypotheses, which are the adverse selection hypothesis and the trading/free-float hypothesis. The former theorizes that informed shareholders who possess greater information over their outside shareholders, could precipitate information asymmetry, and reduce market liquidity (Glosten \& Milgrom, 1985). On the other hand, the latter hypothesis posits that large stakes by blockholders minimizes the available floating shares and hence, the oversight role of insiders' blockholders would cost higher in light of market liquidity. More specifically, with concentrated firm ownership, fewer trades are made and free float is limited, thereby reducing liquidity (Demsetz, 1968; Prommin et al., 2016).

\subsection{Literature Review}

In this section we review the empirical evidence on the relationship between corporate governance and liquidity, followed by evidence on the relationship between ownership structure and liquidity.

\subsubsection{Corporate Governance and Stock Market Liquidity}

Debates abound in literature concerning the effects of corporate governance on market liquidity. In good corporate governance, financial transparency and information disclosure play a significant role, indicating that companies with poor corporate governance are expected to incur greater agency costs and greater asymmetric information risk. Also, providers of liquidity will extend the equity spreads of firms that reflect poor corporate governance, leading to the reduction of market liquidity of equities through the use of price protection action (Chen et al., 2007).

In the context of Saudi Arabia, Alzahrani (2011) examined liquidity in the market with the help of 124 companies, using high frequency intraday data for the years 2005-2008. The study aimed to provide sample evidence linked to liquidity and information asymmetry. The findings showed a price impact asymmetry between buyer-initiated block trades and seller-initiated block trades. More specifically, seller of block trades in the Saudi market incur higher liquidity premium compared to buyers of block trades. The findings showed new evidence based on an order-driven market, with low degree of institutional investor and high ownership concentration.

In a related study, Chung et al. (2012) analyzed the way corporate governance affects stock market liquidity throughout countries having different shareholder protection rights. They employed an extensive survey data on 25 countries spanning years from 2003-2010. Their findings indicated that common law countries had firms with better corporate governance structures and higher stock market liquidity, compared to their civil law counterparts. These results show that legal and regulatory environments for shareholders' protection at the country level, and better corporate governance at the firm level complement each other as robust shareholder protection rights support the efficiency of corporate governance in enhancing stock market liquidity.

More recently, Ali et al. (2016) conducted an analysis of a sample comprising 435 large capitalization Australian firms for the years 2001 to 2008. They revealed that corporate governance positively related with stock liquidity. Similarly, Chung et al. (2010) investigated the association between corporate governance and stock market liquidity 
employing a sample of U.S. stocks and found that firms having robust governance structure had more liquid markets for their share compared to other firms.

Moreover, Silva et al. (2014) delved into the relationship between governance and stock liquidity in the capital market of Brazil. They conducted an analysis using regression of panel data in two models; one with and the other without differentiation in order to consider corporate governance levels (Level 1, Level 2, Novo Mercado) from the years spanning from 2000-2007. Their findings showed an increase in liquidity in companies having enhanced governance but only for Level 1 and Novo Mercado, when individually investigating segments. In the period extending to 2009, including two years of the 2008 financial crisis, no benefits were reaped from governance on stock liquidity. Their findings enabled a comparison between the influence of corporate governance on stock liquidity before crisis and during crisis on the basis of the connections of governance levels and the crisis. Along a similar line of study, Correia and Amaral (2014) determined the factors of market liquidity of shares traded on the São Paulo Stock Exchange for the years 1995-2010. They considered the influence of level of corporate governance, listed on U.S. stock markets and distinct characteristics of the companies in light of dividend policy, accounting profitability, financial structure as well as assets liquidity. They found that liquidity increases with governance, financial slack and return on sales, and that less liquid stock pay more dividends.

Meanwhile, in the Italian stock exchange, Bar-Yosef and Prencipe (2013) investigated the influence of corporate governance and earnings management on market liquidity. They focused on a setting that was known for having highly concentrated non-institutional ownership. They initially reported that high non-institutional ownership leads to higher bid-ask spreads and limits trading volumes, then they showed that trade volume had a tendency to be higher and bid-ask spreads had a tendency to be lower for firms having superior corporate governance mechanisms like board independence and CEO-chairman separation, when high concentration of non-institutional ownership was present. Also in Italy, Elshandidy and Neri (2015) reported that strongly governed firms reflected risk information voluntarily as opposed to mandatorily and this enhanced market liquidity in a considerable manner.

Meanwhile, in North American market, Chung et al. (2010) looked into the relationship between corporate governance and liquidity based on the assumption that effective governance enhances financial and operational transparency and maximizes shareholders' ability to distinguish quality of management and true company value, which could lead to increased shares liquidity. Accordingly, they developed a governance indicator that was based on data obtained from the Institutional Shareholder Services. Their findings showed that companies characterized by good governance and transparency in information disclosure had higher liquidity in the secondary markets, lower information asymmetry and lower possibility for trading on inside information. They reached to the conclusion that good governance results in increased shares liquidity and low equity cost.

In the context of France, Karmani et al. (2015) conducted an analysis of a French company data from the years 2007 to 2012. According to their results, effective and best practices of corporate governance may limit information asymmetry and enhance the companies' market stock liquidity. Furthermore, their results hold up to a different set of liquidity measures.

Moving on to Asian stock markets, Prommin et al. (2014) used a sample of the largest firms in Thailand from the years 2006 to 2009 and found a significant relationship between governance and firms liquidity over time. Specifically, with increased governance quality, liquidity was considerably enhanced. A rise in governance quality by one standard deviation enhanced liquidity ratio by $26.19 \%$. Moreover, in the Chinese stock market, Tang and Wang (2011) investigated the cross-sectional relationship between corporate governance and firm liquidity and revealed robust evidence that the corporate governance level positively associates to firm liquidity. In the context of India, Prasanna and Menon (2012) conducted an empirical study and reported corporate governance positive impact on stock liquidity, with better governed companies displaying higher liquidity. The authors also investigated the association between ownership pattern and stock liquidity, and revealed that higher promoter holdings decreased stock liquidity. The results are consistent with Welker's (1995) arguments concerning ownership dispersion, and it validates the notion that foreign institutional investors and their investments provide liquidity to emerging stock markets, such as the case with India.

In Hong Kong, Shi et al. (2015) employed data obtained from the Hong Kong Stock Exchange to determine the relationship between corporate governance (investor protection at legal and firm levels) and stock market liquidity. They found a relationship between corporate governance issues (investor rights protection at both levels) and stock market liquidity.

Goh et al. (2009) conducted an analysis to look into the relationship between bid-ask spread and governance, with voluntary disclosure as the mediating variable. They reached to the conclusion that better governance in light of 
board of directors' independence and participation of institutional investors in the ownership enhanced liquidity. This relationship was found to be mediated by higher voluntary disclosure, higher analyst coverage, and lower adverse selection. The authors noted that the latter was the primary reason for better governance-higher liquidity relationship. Furthermore, the study of Ferreira and Laux (2007) indicated that better corporate governance and openness to market for corporate control results in higher informative stock prices through the encouragement of collection of and trading on private information.

As for the information asymmetry-liquidity relationship, Diamond (1985) revealed that increased information disclosure mitigates information asymmetry between management and traders, and it reduces the trader's motivation for private information acquisition, which leads to lower heterogeneity among trader beliefs and minimal speculative positions among informed traders. Consequently, it is posited that poor corporate governance prevents stock market liquidity owing to the fact that poor governance reduces transparency in both financial and operational processes. Further, the association between disclosure policy and its influence on market liquidity was elaborated by Welker (1995), who related that disclosure policy impacts stock markets as uninformed investors' price protect against adverse selection and such price protection is reflected through market liquidity. His results showed that a well-developed disclosure policy minimizes information asymmetry and maximizes liquidity in equity markets.

Lastly, Maug (1998) developed a theoretical model to examine the negative liquidity impact against the opposite positive effect - in light of reducing the issue of free-riding of small shareholders. The model explained that the positive effect dominates the negative one (more liquid market leads to effective corporate governance). This was supported by Edmans et al. (2013) who revealed the positive effect of liquidity on corporate governance, with liquidity encouraging large shareholders to put a stake on the firm.

\subsubsection{Ownership Structure and Stock Market Liquidity}

Ownership structure role on liquidity has been debated upon in literature for years. In essence, the theoretical basis upon which ownership-liquidity association is built primarily on agency theory that explains the problem that arises when the agent takes advantage of the control granted by the principal to act on the latter's behalf. Information asymmetry arises when large shareholders have access to privileged firm value information (Heflin \& Shaw, 2000). In this regard, the higher the information asymmetry, the greater the adverse selection cost incurred, which will lead to a larger bid-ask spread. Because of the presence of two types of costs (adverse selection costs and transaction costs), the relationship between ownership structure and liquidity is quite complex in studies. This is compounded by the various types of informed investors, such as managers, majority shareholders and institutional investors (Ajina \& Lakhal, 2010).

On the basis of past literature, Bhide (1993) contended that the presence of blockholders mitigates market liquidity because market makers as well as investors have a tendency to perceive a higher risk of information asymmetry. For instance, Arjoon et al. (2016) investigated companies that listed in Trinidad and Tobago Stock Exchange and revealed that greater institutional coverage was not related with greater liquidity, indicating that institutional owners have information advantages over stock owners. In the Thailand case, Prommin et al.'s (2016) current study showed that firms characterized by concentrated ownership display significant lower stock liquidity. This is because shareholders are expected to hold private information, which leads to information asymmetry and higher adverse selection cost. Consequently, higher ownership concentration is related with lower liquidity.

In the U.S. markets, mixed evidence has been reported concerning the hypothesis that reduced liquidity is a result for the information asymmetries among owners of the company. Chiang and Venkatesh (1988) used a sample of 75 NYSE stocks for 251 trading days from January-December 1973 to examine the way market perceives corporate insiders and institutional holdings via their impacts on the spread. They found insider holdings to positively relate to the dealer's information costs, while controlling for other holding costs and size of the firm. They also found institutional holdings not to have any impact on the spread. Contrastingly, in Rubin's (2007) study, he examined the relationship between firm's stock liquidity and ownership structure - with a focus on how the firm's stock is owned by insiders and institutions, and the level of ownership concentration. His findings revealed that the relationship between liquidity and ownership is largely directed by institutional ownership as opposed to insider ownership. More specifically, his findings revealed liquidity to positively relate to total institutional holdings but negatively so to institutional blockholdings. This result is supported by the hypothesis that while the institutional ownership level proxies for trading activity, the ownership concentration proxies for adverse selection.

More from the U.S. market context, Glosten and Harris (1988) reported an insignificant association between spreads and insider holdings using a sample of 250 NYSE stocks for the years 1981 to 1983. Additionally, Sarin et al. (1996) used a sample of 786 listed U.S. stock for the years April-December 1985 and found that greater insider and 
institutional ownership are both related with wider spreads and smaller quoted depth. Meanwhile, Heflin and Shaw (2000) used a sample of 260 listed U.S. stocks in their study and found that firms having greater blockholder ownership also displayed larger quoted and effective spreads, a larger adverse selection spread, and smaller quoted depths. Moreover, in Canada, Attig et al. (2006) used a sample of publicly-traded firms and reported a difference between ultimate control and ownership that contributes to the widening of the bid-ask spread.

In the same caliber of studies, Iskandrani (2016) examined a sample of 131 companies in the Amman Stock Exchange and revealed that information asymmetry (measured by analysts' coverage) is a key determinant of market liquidity. He specifically showed that market liquidity is less when firms had larger analyst's coverage and high level of ownership concentration.

Similarly, Yosra and Sioud (2011) investigated two empirical associations namely, the ownership concentration-stock liquidity association, and the ownership separation-control/market liquidity association. They empirically found that the structure of ownership was still concentrated in most Tunisian companies and that stock liquidity lessens with concentrated ownership. Owners make use of various devices to gain control and therefore, a considerable separation of ownership from control influences liquidity in various ways. These results show that pyramidal structures significantly and negatively affect liquidity for controlled firms - in contrast, for family-owned firms, non-voting shares heighten liquidity for minority shareholders through the reduction of informed trading probability.

Moreover, in Ding et al.'s (2013) study of the Chinese stock markets, they investigated the effect of foreign institutional investors on liquidity. They initially found that foreign institutional investors' market participation promoted liquidity for two types of enterprises (state owned and non-state-owned). They also found that foreign institutions effect liquidity via informational frictions channel rather than real frictions channel. Also, in China, Chu et al. (2015) used a sample from Chinese listed firms for the years 2005 to 2009 and confirmed that control-ownership divergence negatively affected market liquidity. This finding is aligned with those reported by Attig et al. (2006) in the case of Canada. They also found control-ownership divergence negative influence on market liquidity is higher in firms having serious agency issues and information asymmetry.

In the context of Indonesia, Rhee and Wang (2009) noted that foreign institutions held approximately $70 \%$ of the free-float value of the Indonesian equity market from January 2002 to August 2007, or in effect $41 \%$ of the whole market capitalization. Throughout the same period, the Jakarta Stock Exchange liquidity showed substantial improvement with more than halving of the bid-ask spread, and doubling of the average depth.

Meanwhile, shareholder concentration was reported to have a negative effect on liquidity of the French market by Ajina and Lakhal (2010). Evidently, the controlling shareholder (informed investor), may lessen the information volume on the market and this would lead to high adverse selection costs. They found that large shareholder presence leads to minimal transactions as the private information lies in the hands of few shareholders. Therefore, the cost of private information acquisition increases, and in turn, stock market liquidity decreases. Also, among their findings, institutional investor ownership positively and significantly affected liquidity, and the bid-ask spreads showed shrinkage owing to high frequencies of transactions by the investors that enhances the market liquidity.

In the same context, Ajina et al. (2015) indicated that institutional share-ownership appeared to mitigate bid-ask spreads and enhance stock liquidity. Owing to the diverse portfolios of institutional investors, they trade frequently. This is expected to minimize trading costs and enhance stock liquidity. In other words, in this context, institutional investor ownership is a positive sign by the market that leads to increased mutual trust among investors and enhanced liquidity. Their findings indicated no significant effect of bank and insurance ownership on stock liquidity because with passive investors, no advantage can be obtained from a high rotation of portfolio. Nevertheless, the authors found a positive relationship between pension fund ownership and stock-market liquidity, emphasizing the role of institutional investor in clarifying the liquidity level in the French market.

With regards to the existence of significant blockholders, effective corporate governance mechanisms, particularly board independence may rise to the fore in importance with the increase of perceived risk of information asymmetry as evidenced by Bar-Yosef and Prencipe (2013). With high ownership concentration, owners are able to influence corporate decisions and policies or appoint CEO or board members - lessening the effect of corporate governance mechanisms (Prencipe et al., 2011).

Lastly, proponents of corporate governance advocate that ownership dispersion is required as this would provide liquidity in the market. They stated that ownership concentration leads to limited information that can be accessed by capital markets investors and thus investors deem such firms as high-risks (Prasanna \& Menon, 2012). In other words, retail investors refrain from providing funds to firms and this will result in illiquid stock markets. Becht (1999) 
countered with the argument that ownership dispersion leads to the de-motivation of individual investors to make use of effective management controls, which in turn, have a negative impact on the liquidity of stocks.

\section{Proposed Research Framework}

On the basis of the thorough review of literature, the effects of corporate governance and ownership structure on stock market liquidity is still mixed and inconsistent. This inconsistency can be resolved through the development of a comprehensive framework that could clarify the mechanisms via which the influence of corporate governance could heighten in effectiveness. The framework acts as a guide for empirical studies desiring to examine the determinants of liquidity in the stock market.

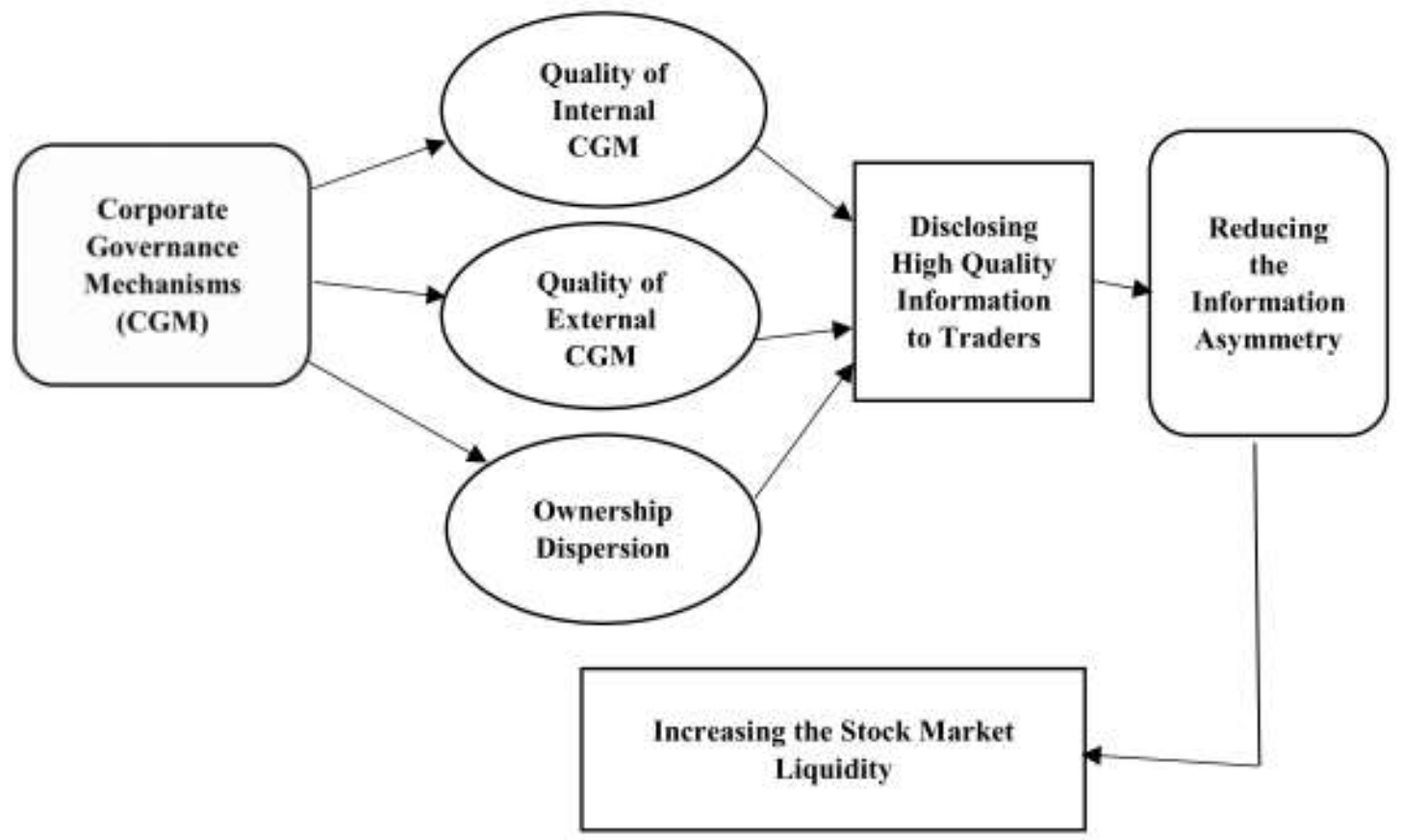

Figure 1. The impact of corporate governance mechanisms on stock market liquidity

\section{Conclusion and Recommendations for Future Research Directions}

Liquidity forms the center element of the development of stock market, as a liquid market is one which is capable of providing allocational efficiency and of facilitating economic growth. For the realization of efficient markets, liquidity is required so that investors are able to trade any amount of security without having to worry about price. However, market imperfections exist that may have certain implications for liquidity. In this paper, the authors attempted to extend literature concerning corporate governance effect on market microstructure devices. It specifically conducts a review of the effect of corporate governance and ownership structure on market liquidity, with particular focus on Saudi institutional context. Saudi firms are characterized by concentrated ownership, with ownership of firms confined in the hands of only a few families and individuals.

Based on literature, effective corporate governance and well-diffused ownership structure improves market liquidity. The findings indicated by studies in different contexts were varied considering the differences of the countries' institutional settings with regards to corporate governance codes and ownership structure. The thorough review of studies indicated that based on agency theory, principals and agents have divergent interests and in the corporate realm, governance mechanisms have been proposed to minimize the possibility that agents will expropriate wealth of principals. Several studies showed that regularly using effective corporate governance practices is related with several benefits to companies, with higher stock liquidity among them.

The proposed research model of our study offers a comprehensive theoretical framework that could be used as reference for empirical examination. The framework was developed and proposed to tackle mixed results concerning the effect of corporate governance mechanisms on stock market liquidity and to shed light on the reason behind the mechanisms failure to generate the expected outcome. Generally speaking, the framework may be used to guide 
future empirical studies to provide greater insight into the effect of corporate governance mechanisms on the stock market liquidity.

Moreover, this paper may have implications for market players in their understanding of the effect of trading practices on stock prices, and for stock exchange authorities in their adoption of effective regulatory policies, and choice of efficient trading systems to mitigate information asymmetry. It also has implications to managers who are desirous of enhancing their shares' market liquidity and accordingly, for their application of effective corporate governance mechanisms.

This study has some recommendations for future research as several questions remain unresolved regarding the effects of corporate governance mechanisms upon market liquidity. Despite the presence of corporate governance in firms, the legal enforcement of statutes for individual protection and stock market liquidity have been acknowledged as components of an efficient market mechanism and the relationship between them have yet to be explored. Future studies would likely obtain more knowledge by exploring them. Moreover, consensus on informed group of investors has yet to be reached in literature - with most studies focused on three investor groups holding superior information namely, institutional investors, blockholders and managers. Therefore, future studies dedicated to market liquidity and ownership should distinguish between the groups owing to their overlapping aspects in extant studies.

Of similar importance, majority of prior studies have concentrated on a single liquidity proxy - but Amihud (2002) related that liquidity is variable that has multiple dimensions and that all the dimensions cannot be encapsulated by using one metric. Therefore, future studies should make use of other liquidity proxies. On a final note, future research may opt to conduct a comprehensive analysis to indicate the way the corporate governance mechanisms-stock liquidity relationship is affected by distinct institutional characteristics in the context of emerging markets, like Saudi Arabia, that is different from those found in the developed markets.

\section{References}

Ajina, A., \& Lakhal, F. (2010). Ownership structure and stock market liquidity in France. Bankers, Markets, Investors, 104. 42-52.

Ajina, A., Lakhal, F., \& Sougné, D. (2015). Institutional investors, information asymmetry and stock market liquidity in France. International Journal of Managerial Finance, 11(1), 44-59. https://doi.org/10.1108/IJMF-08-2013-0086

Al Rajhi Capital, (2014). Saudi Arabian Equity Market Market opening up - A calibrated move. Retrieved from http://www.alrajhicapital.com/en/research/Market/Saudi\%20market\%20report\%20English\%20Aug\%2026\%202 014.pdf

Al-Abbas, M. A. (2009). Corporate governance and earnings management: An empirical study of the Saudi market. Journal of American Academy of Business, 15(1), 301-310.

Alajlan, W. (2015). Ownership patterns and the Saudi market. Corporate Governance, 9, 161-186. https://doi.org/10.1016/S1569-3732(04)09007-3

Albassam, W. (2014). Corporate governance, voluntary disclosure and financial performance: An empirical analysis of Saudi listed firms using a mixed-methods research design. PhD Thesis. University of Glasgow. UK.

Ali, S., Liu, B., \& Su, J. J. (2016). What determines stock liquidity in Australia?. Applied Economics, 48(35), 3329-3344. https://doi.org/10.1080/00036846.2015.1137552

Al-Nodel, A., \& Hussainey, K. (2010). Corporate governance and financing decisions by Saudi companies. Journal of Modern Accounting and Auditing, 6(8), 1-14.

Alsaeed, K. (2006). The association between firm-specific characteristics and disclosure: The case of Saudi Arabia. Managerial Auditing Journal, 21(5), 476-496. https://doi.org/10.1108/02686900610667256

Al-Suhaibani, M., \& Kryzanowski, L. (2000). An exploratory analysis of the order book, and order flow and execution on the Saudi stock market. Journal of Banking \& Finance, 24(8), 1323-1357. https://doi.org/10.1016/S0378-4266(99)00075-8

Alzahrani, A. (2011). Liquidity cost determinants in the Saudi Market. International Journal of Trade, Economics and Finance, 2(3), 185-193. https://doi.org/10.7763/IJTEF.2011.V2.101

Amihud, Y. (2002). Illiquidity and stock returns: cross-section and time-series effects. Journal of Financial Markets, 5(1), 31-56. https://doi.org/10.1016/S1386-4181(01)00024-6 
Amihud, Y., \& Mendelson, H. (1986). Asset pricing and the bid-ask spread. Journal of Financial Economics, 17(2), 223-249. https://doi.org/10.1016/0304-405X(86)90065-6

Amihud, Y., Mendelson, H., \& Wood, R. A. (1990). Liquidity and the 1987 stock market crash. Journal of Portfolio Management, 16(3), 65-69. https://doi.org/10.3905/jpm.1990.409268

Andersen, T. G. (1996). Return volatility and trading volume: An information flow interpretation of stochastic volatility. Journal of Finance, 51(1), 169-204. https://doi.org/10.1111/j.1540-6261.1996.tb05206.x

Arjoon, V., Bougheas, S., \& Milner, C. (2016). Lead-lag relationships in an embryonic stock market: Exploring the role of institutional ownership and liquidity. Research in International Business and Finance, 38, 262-276. https://doi.org/10.1016/j.ribaf.2016.04.012

Attig, N., Fong, W. M., Gadhoum, Y., \& Lang, L. H. (2006). Effects of large shareholding on information asymmetry and stock liquidity. Journal of Banking \& Finance, 30(10), 2875-2892. https://doi.org/10.1016/j.jbankfin.2005.12.002

Bacidore, J. M., \& Sofianos, G. (2002). Liquidity provision and specialist trading in NYSE-listed non-US stocks. Journal of Financial Economics, 63(1), 133-158. https://doi.org/10.1016/S0304-405X(01)00092-7

Bar-Yosef, S., \& Prencipe, A. (2013). The impact of corporate governance and earnings management on stock market liquidity in a highly concentrated ownership capital market. Journal of Accounting, Auditing \& Finance, 28(3), 292-316. https://doi.org/10.1177/0148558X13492591

Becht, M. (1999). European corporate governance: Trading off liquidity against control. European Economic Review, 43(4), 1071-1083. https://doi.org/10.1016/S0014-2921(98)00115-9

Bekaert, G., Harvey, C. R., \& Lundblad, C. (2007). Liquidity and expected returns: Lessons from emerging markets. Review of Financial studies, 20(6), 1783-1831. https://doi.org/10.1093/rfs/hhm030

Belkhir, B., \& Bouri, A. (2008). Ownership structure and bid ask spread: Evidence from Tunisian companies. Corporate Ownership and Control, 5(3), 445-451.

Ben Ali C. (2009). Disclosure quality and corporate governance in a context of minority expropriation. Retrieved from http://papers.ssrn.com/sol3/papers.cfm?abstract_id=1406149. https://doi.org/10.2139/ssrn.1406149

Bhide, A. (1993). The hidden costs of stock market liquidity. Journal of Financial Economics, 34(1), 31-51. https://doi.org/10.1016/0304-405X(93)90039-E

Chen, W. P., Chung, H., Lee, C., \& Liao, W. L. (2007). Corporate governance and equity liquidity: Analysis of S\&P transparency and disclosure rankings. Corporate Governance: An International Review, 15(4), 644-660. https://doi.org/10.1111/j.1467-8683.2007.00594.x

Chiang, R., \& Venkatesh, P. (1988). Insider holdings and perceptions of information asymmetry: A note. Journal of Finance, 43(4), 1041-1048. https://doi.org/10.1111/j.1540-6261.1988.tb02622.x

Chu, X., Liu, Q., \& Tian, G. G. (2015). Does control-ownership divergence impair market liquidity in an emerging market? Evidence from China. Accounting \& Finance, 55(3), 881-910. https://doi.org/10.1111/acfi.12073

Chung, K. H., Elder, J., \& Kim, J. C. (2010). Corporate governance and liquidity. Retrieved from https://www.researchgate.net/profile/Kee_Chung/publication/228301788_Corporate_Governance_and_Liquidit y/links/0fcfd50b62866c95e5000000.pdf. https://doi.org/10.1017/S0022109010000104

Chung, K. H., Kim, J. S., Park, K., \& Sung, T. (2012). Corporate governance, legal system, and stock market liquidity: evidence around the world. Asia-Pacific Journal of Financial Studies, 41(6), 686-703. https://doi.org/10.1111/ajfs.12002

Correia, L. F., \& Amaral, H. F. (2014). Determinants of market liquidity of shares traded on the BM\&FBOVESPA. Brazilian Business Review, 11(6), 75-97. https://doi.org/10.15728/bbr.2014.11.6.4

Das, S. R., \& Hanouna, P. (2009). Hedging credit: Equity liquidity matters. Journal of Financial Intermediation, 18(1), 112-123. https://doi.org/10.1016/j.jfi.2008.08.005

Demsetz, H. (1968). The cost of transactions. Quarterly Journal of Economics, 82(1), 33-53. https://doi.org/10.2307/1882244

Diamond, D. W. (1985). Optimal release of information by firms. Journal of Finance, 40(4), 1071-1094. https://doi.org/10.1111/j.1540-6261.1985.tb02364.x 
Ding, M., Nilsson, B., \& Suardi, S. (2013). Foreign institutional investors and stock market liquidity in China: State ownership, trading activity and information asymmetry. Working paper. Retrieved from http://www.lusem.lu.se/media/kwc/working-papers/2013/kwc-wp-2013-14.pdf. https://doi.org/10.2139/ssrn.2241832

Edmans, A., Fang, V. W., \& Zur, E. (2013). The effect of liquidity on governance. Review of Financial studies, 26(6), 1443-1482. https://doi.org/10.1093/rfs/hht012

Elshandidy, T., \& Neri, L. (2015). Corporate governance, risk disclosure practices, and market liquidity: comparative evidence from the UK and Italy. Corporate Governance: An International Review, 23(4), 331-356. https://doi.org/10.1111/corg.12095

Ferreira, M. A., \& Laux, P. A. (2007). Corporate governance, idiosyncratic risk, and information flow. Journal of Finance, 62(2), 951-989. https://doi.org/10.1111/j.1540-6261.2007.01228.x

FTSE Global Markets 2006. Special GCC Report learning to Live with Volatility. Ftse Global Markets.

Glosten, L. R., \& Harris, L. E. (1988). Estimating the components of the bid/ask spread. Journal of Financial Economics, 21(1), 123-142. https://doi.org/10.1016/0304-405X(88)90034-7

Glosten, L. R., \& Milgrom, P. R. (1985). Bid, ask and transaction prices in a specialist market with heterogeneously informed traders. Journal of Financial Economics, 14(1), 71-100. https://doi.org/10.1016/0304-405X(85)90044-3

Goh, B. W., Ng, J., \& Young, K. (2009). The effect of corporate governance on liquidity: Voluntary disclosure, analyst coverage and adverse selection as mediating mechanisms. Retrieved from https://www.researchgate.net/profile/Kevin_Yong2/publication/228709561_The_Effect_of_Corporate_Governa nce_on_Liquidity_Voluntary_Disclosure_Analyst_Coverage_and_Adverse_Selection_as_Mediating_Mechanis ms/links/5492749c0cf2484a3f3e0d36.pdf

Haddad, A. E., AlShattarat, W. K., \& Nobanee, H. (2009). Voluntary disclosure and stock market liquidity: evidence from the Jordanian capital market. International Journal of Accounting, Auditing and Performance Evaluation, 5(3), 285-309. https://doi.org/10.1504/IJAAPE.2009.026629

Haniffa, R., \& Hudaib, M. (2006). Corporate governance structure and performance of Malaysian listed companies. Journal of Business, Finance and Accounting, 33(7-8), 1034-1062. https://doi.org/10.1111/j.1468-5957.2006.00594.x

Heflin, F., \& Shaw, K. W. (2000). Blockholder ownership and market liquidity. Journal of Financial and Quantitative Analysis, 35(4), 621-633. https://doi.org/10.2307/2676258

Hussainey, K., \& Al - Najjar, B. (2012). Understanding the determinants of risk metrics/ISS ratings of the quality of UK companies' corporate governance practice. Canadian Journal of Administrative Sciences, 29(4), 366-377. https://doi.org/10.1002/cjas.1227

Iskandrani, M. (2016). Market liquidity, analysts coverage, and ownership concentration: evidence from ASE. International Journal of Commerce and Finance, 2(1), 14-24.

Jain, P. K., Kim, J. C., \& Rezaee, Z. (2008). The Sarbanes-Oxley Act of 2002 and Market Liquidity. Financial Review, 43(3), 361-382. https://doi.org/10.1111/j.1540-6288.2008.00198.x

Jeddah Economic Gateway (2015). Saudi Arabian Financial Market November 2015. Retrieved from http://www.jeg.org.sa/data/modules/contents/uploads/infopdf/2810.pdf

Kanagaretnam, K., Lobo, G. J., \& Whalen, D. J. (2007). Does good corporate governance reduce information asymmetry around quarterly earnings announcements? Journal of Accounting and Public Policy, 26(4), 497-522. https://doi.org/10.1016/j.jaccpubpol.2007.05.003

Karmani, M., Ajina, A., \& Boussaada, R. (2015). An investigation of the relation between corporate governance and liquidity: Empirical evidence from France. Journal of Applied Business Research, 31(2), 631-646. https://doi.org/10.19030/jabr.v31i2.9118

La Porta, R., Lopez-de-Silanes, F., Shleifer, A., \& Vishny, R. (2000). Investor protection and corporate governance. Journal of financial economics, 58(1), 3-27. https://doi.org/10.1016/S0304-405X(00)00065-9

Leuz, C., Nanda, D., \& Wysocki, P. D. (2003). Earnings management and investor protection: an international comparison. Journal of financial economics, 69(3), 505-527. https://doi.org/10.1016/S0304-405X(03)00121-1 
Loukil, N., \& Yousfi, O. (2010). Does corporate governance affect stock liquidity in the Tunisian Stock Market? Retrieved from https://mpra.ub.uni muenchen.de/28697/1/MPRA_paper_28697.pdf

Matoussi, H., Karaa, A., \& Maghraoui, R. (2004). Information asymmetry, disclosure level and securities liquidity in the BVMT. Finance India, 18, 547-558.

Maug, E. (1998). Large shareholders as monitors: Is there a trade-off between liquidity and control? Journal of Finance, 53(1), 65-98. https://doi.org/10.1111/0022-1082.35053

Næs, R. (2004). Ownership structure and stock market liquidity. Working paper. Retrieved from http://139.112.129.144/globalassets/upload/import/publikasjoner/arbeidsnotater/pdf/arb-2004-06.pdf

Prasanna, P. K., \& Menon, A. S. (2012). Corporate governance and stock market liquidity in India. International Journal of Behavioural Accounting and Finance, 3(1-2), 24-45. https://doi.org/10.1504/IJBAF.2012.047358

Prencipe, A., Bar-Yosef, S., Mazzola, P., \& Pozza, L. (2011). Income Smoothing in Family-Controlled Companies: Evidence from Italy. Corporate Governance: An International Review, 19(6), 529-546. https://doi.org/10.1111/j.1467-8683.2011.00856.x

Prommin, P., Jumreornvong, S., \& Jiraporn, P. (2014). The effect of corporate governance on stock liquidity: The case of Thailand. International Review of Economics \& Finance, 32, 132-142. https://doi.org/10.1016/j.iref.2014.01.011

Prommin, P., Jumreornvong, S., Jiraporn, P., \& Tong, S. (2016). Liquidity, ownership concentration, corporate governance, and firm value: Evidence from Thailand. Global Finance Journal, 31, 73-87. https://doi.org/10.1016/j.gfj.2016.06.006

Rajan, R., \& Zingales, L. (1998). Financial dependence and growth. American Economic Review, 88(3), 559-586.

Rhee, S. G., \& Wang, J. (2009). Foreign institutional ownership and stock market liquidity: Evidence from Indonesia. Journal of Banking \& Finance, 33(7), 1312-1324. https://doi.org/10.1016/j.jbankfin.2009.01.008

Rösch, C. G., \& Kaserer, C. (2014). Reprint of: Market liquidity in the financial crisis: The role of liquidity commonality and flight-to-quality. Journal of Banking \& Finance, 45, 152-170. https://doi.org/10.1016/j.jbankfin.2014.06.010

Rubin A. (2007). Ownership level, ownership concentration, and liquidity. Journal of Financial Markets, 10(3), 219-248. https://doi.org/10.1016/j.finmar.2007.04.002

Sakawa, H., Ubukata, M., \& Watanabel, N. (2014). Market liquidity and bank-dominated corporate governance: Evidence from Japan. International Review of Economics \& Finance, 31, 1-11. https://doi.org/10.1016/j.iref.2013.11.005

Sarin, A., Shastri, K., \& Shastri, K. (1996). Ownership structure and stock market liquidity. Working paper. Retrieved from https://papers.ssrn.com/sol3/papers.cfm?abstract_id=2652

Saudi Vision $2030 \quad$ (2016). from file:///C:/Users/Mohammed\%20Abdullah/Downloads/Saudi_Vision2030_EN.pdf

Shi, X., Dempsey, M., Duong, H. N., \& Kalev, P. S. (2015). Investor protection and market liquidity revisited. Corporate Governance, 15(4), 517-529. https://doi.org/10.1108/CG-04-2014-0046

Silva, A. C., \& Chávez, G. A. (2008). Cross-listing and liquidity in emerging market stocks. Journal of Banking \& Finance, 32(3), 420-433. https://doi.org/10.1016/j.jbankfin.2007.07.003

Silva, R. L., Nardi, P. C., Martins, V. A., \& Barossi-Filho, M. (2014). Factors Affecting Stock Liquidity: Corporate Governance, ADRs and Economic Crisis. Brazilian Business Review, 11(1), 1-24. https://doi.org/10.15728/bbr.2014.11.1.1

Stulz, R. (1999a). International portfolio flows and security markets. In: International Capital Flows, NBER Conference Report Series, 257-293. https://doi.org/10.2139/ssrn.155188

Tang, K., \& Wang, C. (2011). Corporate governance and firm liquidity: evidence from the Chinese stock market. Emerging Markets Finance and Trade, 47(sup1), 47-60. https://doi.org/10.2753/REE1540-496X4701S105

Tissaoui, K., \& Ftiti, Z. (2016). Liquidity, liquidity risk, and information flow: Lessons from an emerging market. Research in International Business and Finance, 37, 28-48. https://doi.org/10.1016/j.ribaf.2015.09.028 
Wang, J. (2013). Liquidity commonality among Asian equity markets. Pacific-Basin Finance Journal, 21(1), 1209-1231. https://doi.org/10.1016/j.pacfin.2012.06.003

Welker, M. (1995). Disclosure policy, information asymmetry, and liquidity in equity markets. Contemporary Accounting Research, 11(2), 801-827. https://doi.org/10.1111/j.1911-3846.1995.tb00467.x

World Bank (2009). Corporate Governance Country Assessment, Kingdom of Saudi Arabia. Report on Observance of Standards and Codes (ROSC) Program.

Yosra, G., \& Sioud, O. (2011). Ultimate ownership structure and stock liquidity: Empirical evidence from Tunisia. Studies in Economics and Finance, 28(4), 282-300. https://doi.org/10.1108/10867371111171546 